\title{
Protective effects of neem (Azadirachta indica A. Juss) seed oil on carbon tetrachloride-induced hepatotoxicity in Wistar rats
}

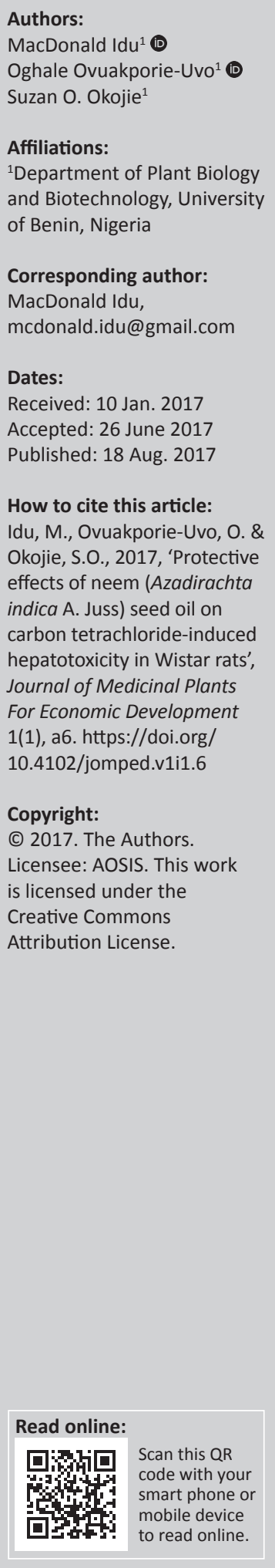

Background: Azadirachta indica (neem) seed oil was evaluated for its hepatoprotective effect. Liver damage was induced using carbon tetrachloride $\left(\mathrm{CCl}_{4}\right)$ while silymarin served as a positive control.

Aim: This study is aimed at testing the hepatoprotective potentials of $A$. indica seed oil on Wistar rats.

Method: Hepatotoxicity was induced by the administration of $1.0 \mathrm{~mL} / \mathrm{kg}$ of $\mathrm{CCl}_{4}$ subcutaneously to 72 healthy Wistar rats of both sexes (weight range: $145 \mathrm{~g}-315 \mathrm{~g}$ ). The seed oil of $A$. indica was orally administered daily in various doses of $0.25 \mathrm{~mL} / \mathrm{kg}, 0.5 \mathrm{~mL} / \mathrm{kg}$ and $1.0 \mathrm{~mL} / \mathrm{kg}$ for 14 days. Animal body and organ weights were recorded, while blood and liver tissues were collected for biochemical, haematological and histological analyses.

Results: Treatment with neem seed oil lowered the aspartate aminotransferase, alanine aminotransferase and alkaline phosphatase levels significantly $(P<0.05)$ in a dose-dependent manner compared to the control. The haematological parameters, organ weight index and animal body weight showed no significant difference $(P>0.05)$ when compared with the control. Histology assessment was in agreement with the biochemical result as tissues of $\mathrm{CCl}_{4}$ exhibited significant fatty tissue accumulation, as opposed to that of $0.25 \mathrm{~mL} / \mathrm{kg}$ neem treatment, which showed only moderate accumulation of fatty tissues, while higher doses, $0.5 \mathrm{~mL} / \mathrm{kg}$ and $1.0 \mathrm{~mL} / \mathrm{kg}$, showed a healthy liver as compared with the control.

Conclusion: The result of this study revealed that neem seed oil had a dose-dependent hepatoprotective effect on the experimental rats.

\section{Introduction}

Plants serve various purposes in the world, one of which is treating various ailments. The neem tree (Azadirachta indica A. Juss) has been known as a wonder tree since time past in the Indian subcontinent. It is now known all over the world majorly because of its relevance in food production and its medicinal properties (Mugnai 2009). Neem plant is the most diverse and versatile tree with maximum useful non-wood products (leaves, barks, flowers, fruits, seeds, gum, oil and neem cake) (Uwimbabazi, Uwimana \& Rutanga 2015). Neem plant popularly known as 'village pharmacy' contains limonoids in its seeds, bark and leaves which have been confirmed to exhibit antiseptic, antiviral, antipyretic, anti-inflammatory, antiulcer and antifungal properties (Nix 2007).

Since time past, herbal medicine has been known as the oldest form of medicine because it is believed to be safe, gentle, accessible and cost friendly (Abebe 2002). However, a standard dose for these herbal drugs is not established and may result in its minimised potential (lesser dosage) or toxicity effect (excess dosage). The physiological activities of neem ( $A$. indica) leaf meal and the responses of rabbits at graded doses have been reported to have mild to moderately toxic effects (Ogbuewu 2008). A 24-hLD ${ }_{50}$ of $14 \mathrm{mg} / \mathrm{kg}$ for acute toxicity in rats has been earlier reported for neem leaf meal. Gomase, Rangari and Verma (2011) reported that young stem bark extract of A. indica plant protected the liver of rats induced with carbon tetrachloride $\left(\mathrm{CCL}_{4}\right)$ using silymarin as a positive control. Doses of $200 \mathrm{mg} / \mathrm{kg}$ and $500 \mathrm{mg} / \mathrm{kg}$ of $A$. indica stem bark extract were reported to steady the functional status of liver cells. Also, neem leaf extract has been observed to provide hepatoprotective effects against paracetamol-induced hepatic cell damage in rats (Gupta, Khosla \& Singh 2008). However, the present study aims at investigating the hepatoprotective activity of neem seed oil in rats induced with liver damage using $\mathrm{CCL}_{4}$. 


\section{Materials and methods Source of oil}

Fresh neem oil (cold pressed) was purchased from Kano State, Nigeria. The oil was authenticated by Professor MacDonald Idu at the herbarium of the Department of Plant Biology and Biotechnology, University of Benin. The oil was kept in a cool and dry place throughout the duration of the experiment.

\section{Experimental animals}

A total of 24 albino rats of both sexes, 4 animals per group with weight range of $145 \mathrm{~g}-315 \mathrm{~g}$, were used for the study. The animals were purchased from a local dealer. They were housed in clean, disinfected cages and allowed free access to feed during the period of the experiment. The animal quarter was a cool and dry place, and animals observed a light-dark cycle. The animals were allowed to acclimatise to the new environment (animal house) for two weeks before the experiment. The animals were fed on pelletised grower mash and clean water. For the purpose of the study, the animals were divided into six groups comprising four animals each. The animals were identified, stained and weighed every three days throughout the duration of the work.

\section{Experimental design}

The $\mathrm{CCl}_{4}$ solution was prepared by mixing $0.2 \mathrm{~mL}$ of $\mathrm{CCL}_{4}$ with olive oil (1:1). The prepared solution was administered to the animals using a dose of $1 \mathrm{mg} / \mathrm{kg}$. All administration of neem oil and silymarin was done orally using an oral gastric tube.

All administration of $\mathrm{CCl}_{4}$ was carried out subcutaneously using sterile disposable needles.

Group 1 control animals received no form of administration.

Group 2 animals were administered $\mathrm{CCl}_{4}$ only.

Group 3 animals were administered silymarin after $\mathrm{CCl}_{4}$ treatment.

Group 4 animals were administered neem oil $(0.25 \mathrm{~mL} / \mathrm{kg})$ after $\mathrm{CCl}_{4}$ treatment.

Group 5 animals were administered neem oil $(0.5 \mathrm{~mL} / \mathrm{kg})$ after being treated with $\mathrm{CCl}_{4}$.

Group 6 animals were administered neem oil $(1 \mathrm{~mL} / \mathrm{kg})$ after being treated with $\mathrm{CCl}_{4}$.

At the end of the two-week experimental period, the animals were fasted overnight prior to the administration of $\mathrm{CCl}_{4}$ except for the control group. This was done for rapid absorption and metabolism of the administered $\mathrm{CCl}_{4}$. Then, animals were sacrificed under chloroform anaesthesia to collect their blood samples through cardiac puncture. The livers, heart, left and right kidneys, spleen and lungs were collected and weighed. The livers were further placed in sterile bottles containing $40 \%$ formaldehyde for subsequent analysis. The blood sample collected from the sacrificed animal was transferred immediately into a lithium heparinised container to avoid clotting, and centrifuged at $4000 \mathrm{rpm}$ for $5 \mathrm{~min}$. After which the supernatant was transferred into a clean tube using a Pasteur pipette for subsequent liver function test. Histopathology was carried out on the harvested liver. The tissues were placed in molten paraffin wax and separated, stained with haematoxylin and eosin and were examined under a light microscope. A photomicroscope (Motic, Canada) was used to take pictures of the micrographs at magnification 100x.

\section{Statistical analysis}

Data were expressed as mean \pm standard error of mean. Statistical analysis was performed using one-way analysis of variance (ANOVA) and Duncan multiple comparisons posttest to separate between the means. Data from the test groups were compared with their respective controls and the differences at $P<0.05$ were regarded as significant.

\section{Results}

Neem seed oil at $0.25,0.5$ and $1.0 \mathrm{~mL} / \mathrm{kg}$ significantly lowered the aspartate aminotransferase (AST), alanine aminotransferase (ALT) and alkaline phosphatase (ALP) levels in a dose-dependent manner when compared with the control. AST, ALT and ALP levels of $\mathrm{CCl}_{4}$-treated rats increased significantly $(P<0.05)$ when compared with the control. All doses of neem oil, positive control and negative control had no significant impact on the total protein (TP) and albumin (ALB) levels when compared with the control (Table 1). No significant difference $(P>0.05)$ was observed in all haematological parameters for animals treated with all doses of neem oil, positive and negative control when compared with the control (Table 2).

Gross examination of animal organs, livers, hearts, spleens, left kidneys, right kidneys and lungs, shows that there was no significant difference $(P<0.05)$ in all animal groups when compared with the control (Table 3). Also, the recorded body weight of animals at various days had no significant difference across the various groups (Table 4 ).

Fatty liver tissues are evident on $\mathrm{CCl}_{4}$-treated animals only (Figure 1b), whereas moderate to mild fatty liver tissues were observed in silymarin (Figure 1c) and $0.25 \mathrm{~mL} / \mathrm{kg}$ neem oiltreated rats (Figure 1d). Normal liver cells radially arranged around portal tracts and central veins were evident in $0.5 \mathrm{~mL} / \mathrm{kg}$ and $1.0 \mathrm{~mL} / \mathrm{kg}$ of neem oil-treated animals (Figure 1e and f), which are similar to control.

\section{Discussion}

Carbon tetrachloride can cause liver damage at $0.5 \mathrm{~mL} / \mathrm{kg}$ body weight (Hewawasam et al. 2004), which was less than the dose administered in this study. Some plants have been 
TABLE 1: Effects of neem seed oil on biochemical parameters of Wistar rats pretreated with $\mathrm{CCl}_{4}(\mathrm{U} / \mathrm{g}$ of wet tissue).

\begin{tabular}{|c|c|c|c|c|c|c|c|}
\hline $\begin{array}{l}\text { Haematological } \\
\text { parameters }\end{array}$ & Control & $\mathrm{CCl}_{4}$ & Silymarin $+\mathrm{CCl}_{4}$ & $\begin{array}{c}\text { Neem oil } \\
(0.25 \mathrm{~mL} / \mathrm{kg}) \\
\end{array}$ & $\begin{array}{c}\text { Neem oil } \\
(0.5 \mathrm{~mL} / \mathrm{kg})\end{array}$ & $\begin{array}{c}\text { Neem oil } \\
(1.0 \mathrm{~mL} / \mathrm{kg})\end{array}$ & $P$ \\
\hline TB (mg/dL) & $0.97^{c} \pm 0.47$ & $1.50^{\mathrm{b}} \pm 0.59$ & $1.97^{a} \pm 0.09$ & $0.38^{c} \pm 0.05$ & $0.45^{c} \pm 0.06$ & $0.57^{c} \pm 0.09$ & $* * P<0.01$ \\
\hline $\mathrm{CB}(\mathrm{mg} / \mathrm{dL})$ & $0.20^{b} \pm 0.06$ & $0.13^{b} \pm 0.03$ & $0.17^{b} \pm 0.03$ & $0.15^{b} \pm 0.03$ & $0.25^{b} \pm 0.03$ & $0.37^{\mathrm{a}} \pm 0.09$ & $* P<0.05$ \\
\hline AST (IU/L) & $108.33^{d} \pm 1.59$ & $168.33^{\mathrm{a}} \pm 1.59$ & $118.33^{b} \pm 1.59$ & $115.88^{c} \pm 1.21$ & $115.33^{c} \pm 1.59$ & $112.75^{d} \pm 1.27$ & $* * P<0.01$ \\
\hline ALT (IU/L) & $56.53^{d} \pm 1.30$ & $116.53^{\mathrm{a}} \pm 1.30$ & $66.53^{b} \pm 1.30$ & $65.15^{b} \pm 1.11$ & $63.53^{c} \pm 1.30$ & $60.65^{c} \pm 1.27$ & $* * P<0.01$ \\
\hline $\operatorname{ALP}(I U / L)$ & $45.30^{\mathrm{e}} \pm 0.93$ & $105.30^{\mathrm{a}} \pm 0.93$ & $55.30^{b} \pm 0.93$ & $53.73^{c} \pm 0.78$ & $52.30^{d} \pm 0.93$ & $50.73^{d} \pm 0.78$ & $* * P<0.01$ \\
\hline TP (g/dL) & $4.97 \pm 1.06$ & $6.37 \pm 1.13$ & $7.33 \pm 0.43$ & $5.28 \pm 0.26$ & $5.33 \pm 0.19$ & $5.90 \pm 0.26$ & $P>0.05$ \\
\hline ALB (g/dL) & $3.07 \pm 0.39$ & $3.20 \pm 0.67$ & $3.63 \pm 0.12$ & $3.18 \pm 0.44$ & $3.88 \pm 0.45$ & $2.53 \pm 0.48$ & $P>0.05$ \\
\hline GLOB (g/dL) & $3.20^{\mathrm{b}} \pm 0.06$ & $2.97^{b} \pm 0.52$ & $3.70^{\mathrm{a}} \pm 0.36$ & $2.10^{c} \pm 0.47$ & $1.55^{c} \pm 0.24$ & $3.37^{b} \pm 0.67$ & $* * P<0.01$ \\
\hline
\end{tabular}

TB, total bilirubin; CB, conjugated bilirubin; AST, aspartate aminotransferase; ALT, alanine aminotransferase; ALP, alkaline phosphatase; TP, total protein; ALB, albumin; GLOB, globulin.

Values are mean $\pm \mathrm{SEM}, n=4 .{ }^{* *} P<0.01$; highly significant, $* P<0.05$; significant compared to control. Different superscripts across rows show the means are significant from others when compared with the control.

TABLE 2: Effect of neem seed oil on haematological parameters of Wistar rats pretreated with $\mathrm{CCl}_{\mathrm{A}}$ ( $\mathrm{U} / \mathrm{g}$ of wet tissue).

\begin{tabular}{|c|c|c|c|c|c|c|c|}
\hline $\begin{array}{l}\text { Biochemical } \\
\text { parameters }\end{array}$ & Control & $\mathrm{CCl}_{4}$ & Silymarin $+\mathrm{CCl}_{4}$ & $\begin{array}{c}\text { Neem oil } \\
(0.25 \mathrm{~mL} / \mathrm{kg})\end{array}$ & $\begin{array}{c}\text { Neem oil } \\
(0.5 \mathrm{~mL} / \mathrm{kg})\end{array}$ & $\begin{array}{c}\text { Neem oil } \\
(1.0 \mathrm{~mL} / \mathrm{kg})\end{array}$ & $P$ \\
\hline$\overline{W B C} \times 10^{3}(\mu \mathrm{L})$ & $13.57 \pm 2.05$ & $11.07 \pm 1.22$ & $12.03 \pm 2.63$ & $18 \pm 5.25$ & $11.45 \pm 3.45$ & $10.13 \pm 0.90$ & $P>0.05$ \\
\hline $\operatorname{LY}(\%)$ & $60.97 \pm 2.26$ & $65.63 \pm 6.27$ & $63.87 \pm 2.66$ & $56.63 \pm 8.56$ & $70.33 \pm 5.33$ & $75.77 \pm 6.50$ & $P>0.05$ \\
\hline MO (\%) & $12.73 \pm 1.73$ & $13.77 \pm 3.10$ & $8.4 \pm 0.81$ & $7.88 \pm 0.55$ & $10.2 \pm 2.25$ & $11.07 \pm 2.83$ & $P>0.05$ \\
\hline GR (\%) & $26.3 \pm 0.57$ & $20.6 \pm 3.35$ & $27.73 \pm 2.07$ & $35.5 \pm 9.08$ & $19.48 \pm 6.16$ & $13.17 \pm 3.70$ & $P>0.05$ \\
\hline $\mathrm{RBC} \times 10^{6}(\mu \mathrm{L})$ & $6.62 \pm 0.16$ & $6.7 \pm 1.44$ & $7.54 \pm 0.53$ & $7.14 \pm 0.40$ & $6.79 \pm 0.61$ & $7.15 \pm 0.27$ & $P>0.05$ \\
\hline HGB $(g / d L)$ & $12.3 \pm 0.85$ & $11.53 \pm 2.44$ & $13.43 \pm 0.75$ & $11.55 \pm 0.6$ & $12.05 \pm 0.47$ & $12.33 \pm 0.58$ & $P>0.05$ \\
\hline HCT (\%) & $34 \pm 1.59$ & $33.33 \pm 6.11$ & $38.63 \pm 1.41$ & $34.5 \pm 1.47$ & $44.53 \pm 9.28$ & $36.43 \pm 2.03$ & $P>0.05$ \\
\hline $\mathrm{PLT} \times 10^{3}(\mu \mathrm{L})$ & $487.33 \pm 26.56$ & $582.33 \pm 15.06$ & $514.33 \pm 81.17$ & $917.25 \pm 205.22$ & $660.25 \pm 181.65$ & $509 \pm 178.55$ & $P>0.05$ \\
\hline
\end{tabular}

Values are mean $\pm \mathrm{SEM}, n=4$ animals. $P>0.05=$ not significant.

The experimental animals were compared with normal groups.

WBC, white blood cells; LY\%, lymphocytes; MO\%, monocytes; GR\%, granulocytes; RBC, red blood cells; HGB, haemoglobin; HCT, haematocrit; PLT, platelets.

TABLE 3: Effects of neem seed oil on organ weight index (g) of Wistar rats pretreated with $\mathrm{CCl}_{4}$

\begin{tabular}{|c|c|c|c|c|c|c|c|}
\hline Organs & Control & $\mathrm{CCl}_{4}$ & Silymarin+ $+\mathrm{CCl}_{4}$ & Neem oil $(0.25 \mathrm{~mL} / \mathrm{kg})$ & Neem oil $(0.5 \mathrm{~mL} / \mathrm{kg})$ & Neem oil $(1.0 \mathrm{~mL} / \mathrm{kg})$ & $P$ \\
\hline Liver & $2.86 \pm 0.28$ & $3.28 \pm 0.27$ & $3.12 \pm 0.27$ & $4.4 \pm 0.46$ & $4.55 \pm 0.28$ & $4.6 \pm 0.63$ & $P>0.05$ \\
\hline Heart & $0.18 \pm 0.05$ & $0.17 \pm 0.06$ & $0.23 \pm 0.02$ & $0.13 \pm 0.02$ & $0.15 \pm 0.01$ & $0.48 \pm 0.22$ & $P>0.05$ \\
\hline Spleen & $0.19 \pm 0.09$ & $0.14 \pm 0.03$ & $0.19 \pm 0.03$ & $0.11 \pm 0.05$ & $0.15 \pm 0.06$ & $0.19 \pm 0.05$ & $P>0.05$ \\
\hline Left kidney & $0.19 \pm 0.05$ & $0.18 \pm 0.06$ & $0.23 \pm 0.02$ & $0.15 \pm 0.06$ & $0.13 \pm 0.02$ & $0.14 \pm 0.01$ & $P>0.05$ \\
\hline Right kidney & $0.2 \pm 0.07$ & $0.21 \pm 0.08$ & $0.23 \pm 0.02$ & $0.15 \pm 0.04$ & $0.14 \pm 0.03$ & $0.16 \pm 0.01$ & $P>0.05$ \\
\hline Lung & $0.69 \pm 0.01$ & $0.48 \pm 0.06$ & $0.54 \pm 0.13$ & $0.48 \pm 0.08$ & $0.48 \pm 0.04$ & $0.46 \pm 0.06$ & $P>0.05$ \\
\hline
\end{tabular}

Values are mean \pm SEM for 3-4 animals in each observation, $P>0.05=$ not significant. The experimental animals were compared with normal groups.

TABLE 4: Effects of neem seed oil on body weight of Wistar rats pretreated with $\mathrm{CCl}_{4}$

\begin{tabular}{|c|c|c|c|c|c|}
\hline Treatment groups & Day 0 & Day 4 & Day 9 & Day 14 & $P$ \\
\hline Control & $200.0 \pm 5.00$ & $205.0 \pm 10.00$ & $218.33 \pm 11.67$ & $215.0 \pm 21.79$ & $P>0.05$ \\
\hline $\mathrm{CCl}_{4}$ & $215.0 \pm 23.63$ & $226.67 \pm 31.80$ & $206.67 \pm 10.14$ & $236.67 \pm 26.82$ & $P>0.05$ \\
\hline Silymarin $+\mathrm{CCl}_{4}$ & $186.67 \pm 24.55$ & $191.67 \pm 14.81$ & $195.0 \pm 15.00$ & $205.0 \pm 13.23$ & $P>0.05$ \\
\hline Neem oil $(0.25 \mathrm{~mL} / \mathrm{kg})$ & $237.5 \pm 8.54$ & $243.75 \pm 7.47$ & $251.25 \pm 12.97$ & $248.75 \pm 13.90$ & $P>0.05$ \\
\hline Neem oil $(0.5 \mathrm{~mL} / \mathrm{kg})$ & $222.5 \pm 12.67$ & $226.25 \pm 15.19$ & $232.5 \pm 11.27$ & $232.5 \pm 11.27$ & $P>0.05$ \\
\hline Neem oil $(1.0 \mathrm{~mL} / \mathrm{kg})$ & $268.33 \pm 23.33$ & $265.0 \pm 28.43$ & $280.0 \pm 25.17$ & $286.67 \pm 25.22$ & $P>0.05$ \\
\hline
\end{tabular}

$P>0.05=$ not significant; there are no differences between each treatment group across the days.

shown to have protective effects against organ damage, especially those caused by daily exposure to toxins (Amole \& Ilori 2010). In the present study, the total bilirubin level increased significantly $(P<0.05)$ in serum of animals administered with $\mathrm{CCl}_{4}$ and those co-administered with $\mathrm{CCl}_{4}$ and silymarin as compared to the control. However, the lower the dose of the neem seed oil, the more the total bilirubin decreased significantly $(P<0.05)$ compared with the control. These observations are in line with the research findings of Prakash et al. (2008), suggesting that neem oil is more potent than the control drug in maintaining total bilirubin in animals. Conjugate bilirubin increased significantly $(P<0.05)$ in $1.0 \mathrm{~mL} / \mathrm{kg}$ of neem oil treatment when compared with control animals. However, there was no significant difference $(P>0.05)$ in the conjugated bilirubin across the other groups. TP and ALB had no significant difference $(P>0.05)$ across the various groups, showing that $\mathrm{CCl}_{4}$, silymarin and neem oil had no effect on the animals' TP and ALB in this study. However, globulin of animals with $\mathrm{CCl}_{4}$ treatment only and neem seed oil treatment $(1.0 \mathrm{~mL} / \mathrm{kg})$ had no significant difference with that of the control group. Animals treated with $0.25 \mathrm{~mL} / \mathrm{kg}$ and $0.5 \mathrm{~mL} / \mathrm{kg}$ neem oil had a significantly different $(P<0.05)$ globulin level from that of the control.

AST (Range: 108-168), ALT (Range: 56-116) and ALP (Range: $45-105)$ values significantly increased $(P<0.05)$ in the $\mathrm{CCl}_{4}$ group. This is in agreement with Kumar et al. 

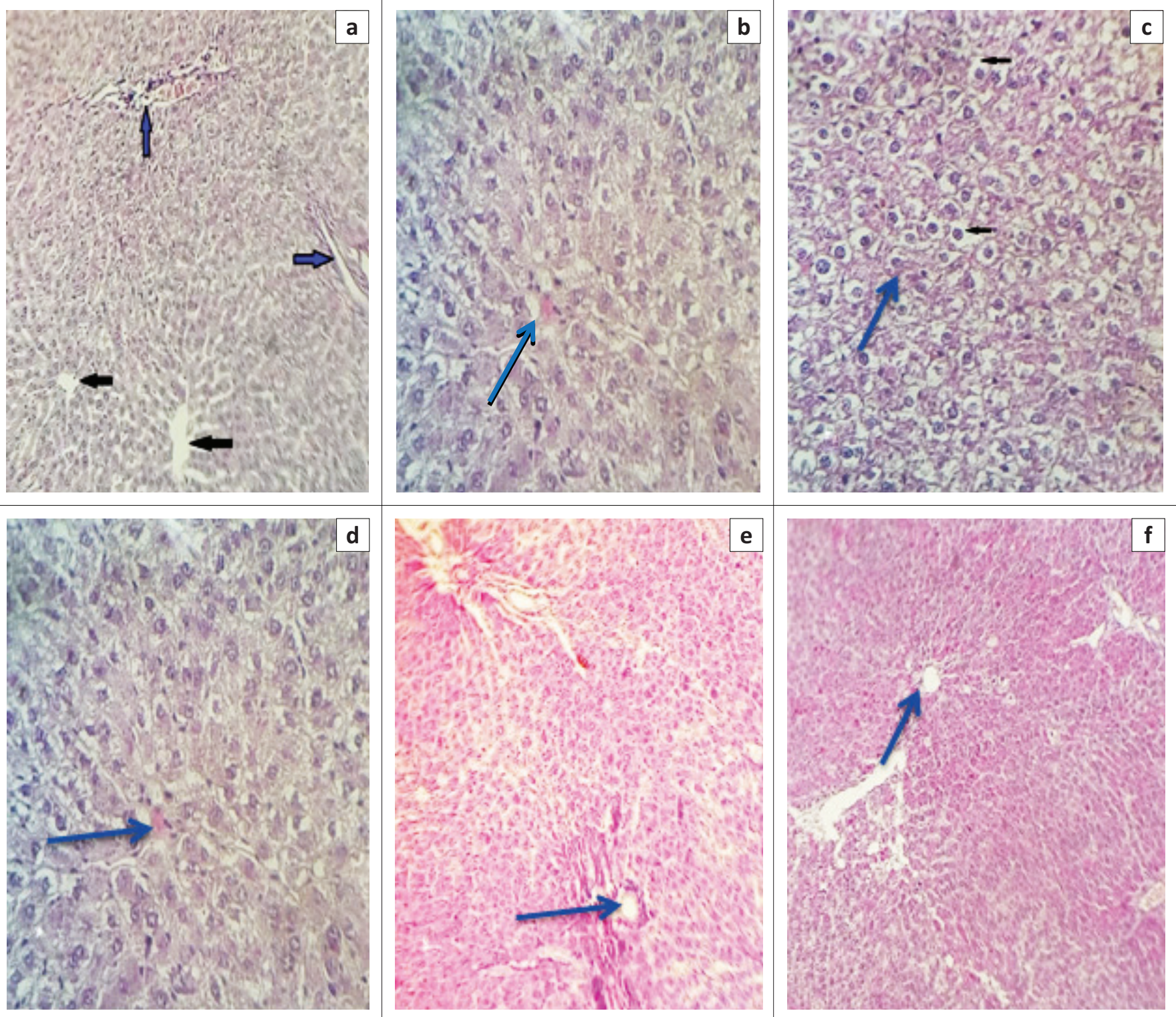

Source: Authors' own work.

FIGURE 1: (a) Section of rat liver from control rats showing control rat with normal liver cells radially arranged around portal tracts (blue arrows) and central veins (black arrows) (100x). (b) Rat liver from negative control (CCl administration alone) with accumulation of fat in the cytoplasm of liver cells (blue arrows) (100x). (c) Rat liver from positive control ( $\mathrm{CCl}_{4}+$ silymarin) showing fatty change (blue arrow) (100x). (d) Liver section from rats treated with Azadirachta indica oil extract (0.25 $\mathrm{mL} / \mathrm{kg}$ ) and $\mathrm{CCl}$ showing fatty change (blue arrow) (100x). (e) Liver section from rats treated with Azadirachta indica oil extract $(0.5 \mathrm{~mL} / \mathrm{kg}$ ) and CCl showing normal liver cells radially

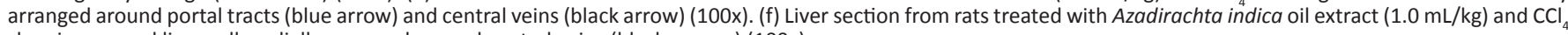
showing normal liver cells radially arranged around central veins (black arrows) (100x)

(2009), Kaplowitz (2004), Kelly and Skidmore (2002), Basu (2003), Manibusan, Odin and Eastmond (2007) and Planaguma et al. (2005) who reported significant increase in the enzyme activity on administration of $\mathrm{CCl}_{4}$. The reduction of the ALT, AST and ALP values decreased with increase in dose of neem oil when compared with the $\mathrm{CCl}_{4}$ group only. More so, silymarin-treated groups had reduced ALT, AST and ALP values when compared with the control. This suggests that neem oil is more active at a higher dose $(1.0 \mathrm{~mL} / \mathrm{kg}$ ) and more effective than silymarin (a known hepatoprotective drug).

There was no significant difference $(P>0.05)$ in the haematological parameters in all groups. This observation suggests that neem oil (dose: $0.25 \mathrm{~mL} / \mathrm{kg}, 0.5 \mathrm{~mL} / \mathrm{kg}$,
$1.0 \mathrm{~mL} / \mathrm{kg}), \mathrm{CCl}_{4}(1 \mathrm{~mL} / \mathrm{kg})$ and silymarin $(1 \mathrm{mg} / \mathrm{kg})$ had no effect on the haematological parameters. The organ weight index and animal body weight were insignificant $(P>0.05)$ across the various groups in this study. This observation suggests that neem seed oil, $\mathrm{CCl}_{4}$ and silymarin had no effect on organ weight and body weight.

Histological studies of liver tissues in each group are in agreement with the biochemical result in this study. High fat accumulation and massive necrosis were observed in the liver tissue of animal group administered with $\mathrm{CCl}_{4}$ only. However, groups treated with silymarin and $0.25 \mathrm{mg} / \mathrm{kg}$ neem oil had a moderate fatty liver. In addition, liver tissues of control and $1.0 \mathrm{mg} / \mathrm{kg}$ of neem oil-treated group had a normal liver. This suggests that the neem oil dose $1.0 \mathrm{~mL} / \mathrm{kg}$ 
is more effective than the lower doses in protecting the liver against $\mathrm{CCl}_{4}$ damage. This might be because of the presence of some phytocompounds present in neem, which improve the ability of the liver to detoxify itself of chemical contamination (Ogbuewu et al. 2011).

This study reveals that neem oil is hepatoprotective $(0.25 \mathrm{~mL} / \mathrm{kg}, 0.5 \mathrm{~mL} / \mathrm{kg}, 1.0 \mathrm{~mL} / \mathrm{kg}$ ) but might become toxic at a comparatively higher dose. Neem seed oil has been reported to show acute toxicity in rats and rabbits with LD50 of $14 \mathrm{mg} / \mathrm{kg}$ and $24 \mathrm{mg} / \mathrm{kg}$, respectively, possibly targeting organs for toxic effects, especially the central nervous system and the lungs (Gandhi et al. 1988).

\section{Conclusion}

In conclusion, $A$. indica oil extract showed hepatoprotective activities. The activities were graded dose dependent. Furthermore, the hepatoprotective function of neem oil was comparable to the standard drug (silymarin). However, more work needs to be carried out on determining the toxicity profile (biosafety) of neem seed oil.

\section{Acknowledgements}

The authors wish to thank Mr Dickson for his assistance in the lab. They also appreciate Alhaji Rano for his assistance in helping them purchase locally extracted neem oil from Kano State, Nigeria.

\section{Competing interest}

The authors declare that they have no financial or personal relationships which may have inappropriately influenced them in writing this article.

\section{Authors' contributions}

M.I. designed this study and gave directions for its implementation. O.U-.O. helped to organise the results, proofread the final draft of the article and put it in the journal format. S.O.O. carried out the bench work with laboratory assistants and wrote the first draft of this article.

\section{References}

Abebe, W., 2002, 'Mechanisms of liver cell injury', Journal of Herpetology 32, 39-47.

Amole, O.O. \& Ilori, O.O., 2010, 'Antimicrobial activity of the aqueous and ethanolic extracts of the stem bark of Alstonia boonei', International Journal of Phytopharmacology 1, 119-123.

Basu, S., 2003, 'Carbon tetrachloride-induced lipid peroxidation: Eicosanoid formation and their regulation by antioxidant nutrients', Toxicology 18(9), 113-127. https:// doi.org/10.1016/S0300-483X(03)00157-4

Gandhi, M., Lal, R., Sankaranarayanan, A., Banerjee, C.K. \& Sharma, P.L., 1988, 'Acute toxicity study of the oil from Azadirachta indica seed (neem oil)', Journal of Ethnopharmacology 23, 39-51. https://doi.org/10.1016/03788741(88)90113-4

Gomase, P.V., Rangari, V.D. \& Verma, P.R., 2011, 'Phytochemical evaluation and hepatoprotective activity of fresh juice of young stem (tender) bark of Azadirachta indica A. Juss', International Journal of Pharmacy and Pharmaceutical Sciences $3(2), 55-59$.

Gupta, A., Khosla, P. \& Singh, T.K., 2008, 'Effect of neem leaf extract on isolated perfused preparation', Indian Journal of Pharmacology 32, 132-175.

Hewawasam, P., Chen, N., Ding, M., Natale, J.T., Boissard, C.G., Yeola, S. et al., 2004, 'The synthesis and structure-activity relationships of 3-amino-4-benzylquinolin-2 ones; discovery of novel KCNQ2 channel openers', Bioorganic \& Medicinal Chemistry 14(7), 1615-1618. https://doi.org/10.1016/j.bmcl.2004.01.073

Kaplowitz, N., 2004, 'Drug-induced liver disorders: Implications for drug development and regulation', Drug Safety 24, 483-490. https://doi.org/10.2165/00002018200124070-00001

Kelly, D. \& Skidmore, S., 2002, 'Hepatitis C-Z: Latest treatment options', Archives of Disease in Childhood 86, 339-343. https://doi.org/10.1136/adc.86.5.339

Kumar, P.V., Sivaraj, A., Elumalai, E.K. \& Senthil Kumar, B., 2009, 'Carbon tetrachlorideinduced hepatotoxicity in rats-protective role of aqueous leaf extracts of Coccinia grandis', International Journal of PharmTech Research 1(4), 1612-1615.

Manibusan, M.K., Odin, M. \& Eastmond, D.A., 2007, 'Postulated carbon tetrachloride mode of action: A review', Journal of Environmental Science and Health 25 , 185-209. https://doi.org/10.1080/10590500701569398

Mugnai, E., 2009, Azadirachta indica: Neem tree, the 'village pharmacy', ASATAssociazione Scienze Agrarie Tropicali, Firenze.

Nix, S., 2007, 'Neem tree - "The Village Pharmacy"', viewed from www.forestry. about.com.

Ogbuewu, I.P., 2008, 'Physiological responses of rabbits fed graded levels of neem (Azadirachta indica) leaf meal', MSc thesis, Federal University of Technology, Owerri.

Ogbuewu, I.P., Odoemenam, V.U., Obikaonu, H.O., Opara, M.N., Emenalom, O.O., Uchegbu, M.C. et al., 2011, 'The growing importance of neem (Azadirachta indica A. Juss) in agriculture, industry, medicine and environment: A review', Research Journal of Medicinal Plant 5(3), 230-245. https://doi.org/10.3923/ rjmp.2011.230.245

Planaguma, A., Claria, J., Miquel, R., López-Parra, M., Titos, E., Masferrer, J.L. et al., 2005, 'The selective cyclooxygenase-2 Inhibitor SC- 236 reduces liver fibrosis by mechanisms involving non-parenchyma cell apoptosis and PPAR gamma activation', FASEB Journal 19, 1120-1122.

Prakash, T., Fadadu, S.D., Sharma, U.R. \& Dupadahalli, K., 2008, 'Hepatoprotective activity of leaves of Rhododendron arboreum in $\mathrm{CCl}$ induced hepatotoxicity in rats', Journal of Medicinal Plants Research 2(11), 315-320.

Uwimbabazi, F., Uwimana, J. \& Rutanga, J.P., 2015, 'Assessment of antibacterial activity of neem plant (Azadirachta indica) on Staphylococcus aureus and Escherichia coli', Journal of Medicinal Plants Studies 3(4), 85-91. 